Tarih Kültür ve Sanat Araştırmaları Dergisi

Revue des Recherches en Histoire Culture et Art

مجلة البحوث التاريخية و الثقافية والفنية
Vol. 7, No. 1, March 2018

Copyright (C) Karabuk University

http://kutaksam.karabuk.edu.tr

\title{
DOI: 10.7596/taksad.v7i1.1447
}

Citation: Sadykova, E., \& Basharan, V. (2018). The Mechanism of Educational Institutions in the Dialogue of Civilizations: The Example of the Conference "Russia and Islamic World". Journal of History Culture and Art Research, 7(1), 40-45. doi:http://dx.doi.org/10.7596/taksad.v7i1.1447

\section{The Mechanism of Educational Institutions in the Dialogue of Civilizations: The Example of the Conference "Russia and Islamic World"}

\section{Elmira Lenarovna Sadykova ${ }^{1}$, Venera Ilmirovna Basharan ${ }^{2}$}

\begin{abstract}
International scientific and practical conference "Russia and Islamic world", organized by the Center Islamic researches of the Academy of Sciences of Tatarstan, is a considerable example of educational institutions that took part in the dialogue among cultures and civilizations. In the article, the authors analyze how the development of such mechanism as educational institutions helps on the preservation of cultural heritage, strengthening interethnic peace and accord, intercultural and inter-religious dialogue, establishing a stable and effective cooperation of Tatarstan with international organizations, such as UNESCO, OIC etc. The objective of the study implies search not only one conference, but also mechanisms for development coordination and cooperation in intercultural and inter civilizational dialogues. It draws a conclusion about the necessity to expand cooperation between universities, exchange of views and experience; it can be also manifested in the organization of joint conferences like "Russia and Islamic world".
\end{abstract}

Keywords: Educational institutions, Intercivilizational dialogue, Islamic world, Regionalism, Conference "Russia-Islamic world".

\footnotetext{
${ }^{1}$ Kazan Federal University. E-mail: richone@rambler.ru

${ }^{2}$ Kazan Federal University. E-mail: vinercik@hotmail.com
} 


\section{Introduction}

The problem of the dialogue among civilizations is a subject of discussion of researchers, politicians, public figures, representing different countries and regions of the world. Nowadays states in their bilateral and multilateral contacts, in addition to the traditional issues of political, economical and humanitarian character, discussing "dialogue of civilizations or of cultures", "inter-religious dialogue", involve the institutions of civil society, thus discussing the situation and prospects of development of intercultural or inter-civilizational dialogue, its basics, objectives and principles as well as the institutions involved in its development.

Many researchers, who raise the issue, highlight the importance of mutual exchange of information, when all parties have the opportunity to express their opinions (Chernokozheva, 2009). Meanwhile it is more often stressed the necessity to realize and develop various programs and activities for intercultural communication, especially in education. Participation at all levels has a particular importance.

On many occasions, we are speaking about dialogue among civilizations, in the context of the relationship of states with the Islamic world. According to Laqueur, "Russia emphasized its respect for Islam, the Muslim countries and their leaders, as well as the need to promote reconciliation between different cultures and civilizations, but at the same time, Russia's internal Muslim problems are no doubt of greater political importance than its relations with foreign Muslim countries" (Laqueur, 2009). A large number of conferences are on issues associated with Islam in which participate both Russian and foreign delegates. One of these conferences is "Russia and Islamic world".

\section{Methodological Framework}

Analyzing the development of the mechanism of educational institutions in the dialogue of civilizations on the example of the conference "Russia and Islamic world", allows presenting an objective academic picture of the development of the international cooperation both in the educational sphere and Islamic issue. The methodological basis of the presented work is scientific objectivity, the principles of historicism and systematization, analysis of specific situations, description of them, their comparison and drawing conclusions.

\section{Results}

First conference under name "Russia and Islamic world" was international conference "Russia and Islamic world: partnership for stability" held on 24th September 2009 in Moscow in the House of Unions. This international conference was one of the largest events held by the Islamic community of Russia. The purpose of the conference was expansion of international cooperation of Russia with the countries of the Muslim world and Islamic organizations of Europe and the USA in the field of science, culture and economy. Considerable attention was paid to the role of religious organizations - the spiritual administration of Muslims and other Islamic religious centers, united in the Council of Muftis of Russia. The Russian Muslim forum coincided with the international celebration of the 40th anniversary of the Organization of the Islamic Conference (OIC). Russia was accepted to this authoritative international Islamic organization in observer status in 2005. President of Russia Vladimir Putin was visited Kuala Lumpur in November 2003, attended the summit of the OIC, where he strengthened the fact that Russia is home to 20 million Muslims. According to Derrick, "while some observers questioned Putin's appeal for OIC membership, seeing his request as driven by geopolitical or economic motives, his acknowledgement on a world stage that Russia in fact is part of the Muslim world is better understood as part of a nationbuilding process. Putin was speaking directly to Muslims of Russia as part of what he called 
"consolidation" of the "multinational Russian people", a nation that, in Kuala Lumpur, he made clear was also multi-religious" (Derrick, 2012).

This vision was also confirmed by the participants of the conference in 2009. Speakers emphasized that Russia is not only Orthodox, but also Muslim country, highlighted the role of Muslims in the multinational and multi-confessional state, that the tolerance of Islam in Russia is cementing foundation for the Russian statehood (Naumkin, 2009). Importance of Russia's cooperation with the OIC was devoted too. Matters related to the economic cooperation of Russia and Islamic States, the information policy of Russian Muslims, Islamic education, etc., were also raised (Gaynutdin, 2009). The contribution of the conference in understanding the meaning of Islam, that only peace, unity and understanding of interactions give to the country and the world the prospects for the future that the culture of peace is the underlying basis of human life were strengthened (Luzhkov, 2009).

In 2011 in Ufa the international scientific and practical conference "Russia and Islamic world: history and prospects of civilized interaction" was devoted to the 120th anniversary of the birth of a diplomat and a public figure Karim Khakimov. Within two days representatives of the academic community, diplomatic corps, public organizations and intellectuals from many regions of Russia and countries discussed the current problems of modern state of Russian-Arab relations, economic and cultural cooperation, the history of diplomacy, Russia's policy in the middle East, the integration of the Islamic world and culture in Russia and in the West. The resolution of the scientific forum noted that one of the most important geopolitical task is the preservation and strengthening of good neighborly relations of Russia with the countries of the Middle East. The conference offered more widely to promote the scientific achievements of Orientalists. In the outcome document of the conference noted that, historically, Islam is an integral part of Russian spiritual heritage, it carries universal values, gives examples of religious tolerance and respect for different cultures (Nafikova, 2011).

On the $17^{\text {th }}$ November 2016 there was an international scientific-practical conference "Russia and Islamic world: the search for the response to the globalization of extremist movements" in Kazan. Islamic scholars, sociologists, historians, political scientists and other experts in the field of Islam were participated to this conference. The main message of speeches was drawing attention to the return of the religious factor in the active public sphere, politics and international relations; that restoration of ethnocultural relations between generations, on the other hand, led to the radicalization and expansion of antistate and anti-social manifestations, and that one of the main problems for countries with a dominant Islamic component is the spread of radical ideologies. Working sections and panel discussions in this conference were as follows: The manifestations of religious radicalism in the Middle East and other regions of the world; Religious extremism in Russia and the CIS countries; Experience of combating and prevention of religious extremism (The Spiritual Administration of Muslims of the Republic of Tatarstan, 2016).

In 2017 in the city of Kazan hosted the international scientific and practical conference "Russia and Islamic world: directions of interaction and the searches for an answer to the challenges of modernity». This conference was organized by the Group of strategic vision "Russia - Islamic world", the Russian Foundation for basic research, Academy of Sciences of the Republic of Tatarstan, Center of Islamic researches of the Academy of Sciences of the Republic of Tatarstan. Within the event was held a discussion of general and specific aspects in cultural, religious and socio-political space of the Islamic world, the specifics of the development of the Muslim community in the central and peripheral regions. Special attention was paid to the problem of transformation of radical ideas in the context of globalization, the theory and practice of traditional forms of Islam in historical perspective, and the interaction of Islam with other religions (Christianity, Judaism, etc.). During the conference different working sections and panel discussions were organized. Some of them were as follows: The Islamic world 
in a globalization transformations; The threat of radicalism in the context of the development of the strategic relations between Russia and the Islamic world; Historical and contemporary interrelations of Russia and CIS countries with the Islamic world; Civilizational aspects of interreligious dialogue between Islam and Orthodoxy; The interaction between Russia and the Islamic world through the eyes of young scientists. According to the participants of the conference in 2017, it is important to think about both dialogue, and transition from dialogue to real partnership. Republic of Tatarstan is a vivid example of that how the prospects of this partnership can look like (The Group of Strategic Vision Russia - Islamic world, 2017).

\section{Discussion}

Many conferences on the problems of dialogue of civilizations were held (Yakovets, 2014). The education and culture in Russian authors' researches are often presented like two sides of a single process of development of mankind and society (Vetchinova, 2011), dialogue of cultures most often was studied in their works in the framework of the European vision of culture and was initiated with the Western culture (Ornatskaya, 2014). M.M. Lebedeva noted very remarkable aspect: only through education, states can develop dialogue of cultures, moreover, civilizations. Author discussed peculiarities of educational resources for centuries, the relevance of education at all times; statistical data; studied the integration processes in educational sphere; the role of education and upbringing in the formation of the educational process, etc. Vetchinova (2011) has raised the similar issues. The given examples demonstrate that researches in which conferences studied as educational institutions in dialogue among civilizations has not been submitted, despite the fact that the theme of the dialogue of civilizations presented in many articles in various aspects. As an example, it is possible to show article of Guseynov (2007), where he discusses issues that should enter the public discourse in the dialogue of cultures, what should be the scope, wording, etc.

\section{Conclusion}

In recent years, an issue of the education in context of intercultural dialogue was discussed on the world conferences, specialized forums like: UNESCO world conferences on education, world summits on sustainable development, International UN conference on financing for development etc. International organizations like the Organization for economic cooperation and development (OECD), World Bank, WTO are also involved in researching problems of education in collaboration with UNESCO.

The development of education is a crucial contribution to the development of dialogue between civilizations. The most important moment in the inter-cultural dialogue is the role of a University in modern society. Educational, scientific and practical aim of the conference is the development and implementation of a new strategy of dialogue and partnership of civilizations. Every year the conditions and challenges for this dialogue change, but answers for many of them can be obtained at conferences. One such notable example is the international scientific and practical conference "Russia and Islamic world".

In regard to development of the themes of the conference, it becomes evident that the most fundamental factor was the recognition that Russia is a multi-confessional country, and therefore tolerance should be the basis of all national, cultural, and on a larger scale, civilizational relations. At such educational institutes like conferences especially this one, which focused on different (not only educational but religious and governmental) segments of society, pay attention to wide questions and concepts. The value of any educational conference is in the clarification and specification of well-known concepts, as well as in 
the systematization and generalization of knowledge. There were specific suggestions on conferences that Islam in Russia should also be studied as part of the history and culture of Russia.

Along with the turn to global problems in 2016-2017 years, like image of Islam all over the world, extremist movements, aggressive geopolitics, radical ideologies etc., in our opinion, the two most important discussion sections from the point of view of the aspect of our article like "Civilizational aspects of interreligious dialogue between Islam and Orthodoxy" and "The interaction between Russia and the Islamic world through the eyes of young scientists" appeared. Theme of civilizational aspect certifies that educational structure is trying to solve complicated issues of protection of national interests of our country, that it also creates an important platform for exchange of ideas and development of initiatives and concrete solutions, creates a positive attitude towards other communities, etc.

The Republic of Tatarstan is a vivid example of the peaceful coexistence of different cultures and confessions. The programs realized by the Republic can be studied for researches of the conceptual questions on the dialogue of civilizations.

A culture of interreligious dialogue and creating conditions for mutual understanding in reality require the implementation of constructive policies in different areas. Conference is one of the perspective forms and tendency of development of educational sphere in modern world, it should be noted the fact that education is essentially inexhaustible. Dialogue in turn leads to the enhancement of the educational resource.

It can be concluded that discussion the dialogue among civilizations should be based on broad cooperation between universities, exchange of views and experiences, both within Russia and internationally. Organization of joint conferences and round tables is an important part of this cooperation. All this will lead also to the importance of science and increase its role in society, based on scientific knowledge.

\section{Recommendations}

Article is intended for experts in dialogue among civilizations, cultures, religions, history of oriental studies, as well as history of relationship of Russia with the Islamic world.

\section{Acknowledgments}

The work is performed according to the Russian Government Program of Competitive Growth of Kazan Federal University.

\section{References}

Chernokozheva, E. (2009). Intercultural dialogue: concepts and practical steps. Society, environment, development (Terra Humana), 105-109.

Derrick, M. A. (2012). Placing faith in Tatarstan, Russia: Islam and the negotiation of Homeland. Dissertation presented to the Department of Geography and the Graduate School of the University of Oregon in partial fulfillment of the requirements for the degree of Doctor of Philosophy. 
Guseynov, A. (2008). What we are talking about when we speak about the dialogue of civilizations. International Affairs, 3, 34-43.

Laqueur, W. (2009). Russia's Muslim Strategy, Middle East Papers. Middle East Strategy at Harvard, November 1, 6, 1-12.

Lebedeva, M. (2009). The role of education in the dialogue of civilizations. Vestnik MGIMO-University, 2(5).

Nafikova, A. (2011). The bridge of friendship on the crossroads of civilizations. Conference "Russia and Islamic world" will become traditional. Republic of Bashkortostan. № 59. URL: http://www.agidel.ru/?param1=22199\&tab=2

Official web-site of the Group of Strategic Vision "Russia - Islamic world". URL: $\quad$ http://rusisworld.com/novosti-gruppy/v-kazani-zavershilas-konferenciya-rossiya-i-islamskiy-mirnapravleniya

Official web-site of the spiritual administration of Muslims of the Republic of Tatarstan. URL: http://dumrt.ru/ru/news/news_15745.html

Ornatskaya, L. (2014). Intercultural dialogue: problems and prospects of research. Vestnik of Saint Petersburg University, 6(1), 48-60.

Speech of Ravil Gaynutdin at the Conference "Russia and Islamic world: partnership for stability", $24^{\text {th }}$ September 2009.

Speech of Vitaliy Naumkin at the Conference "Russia and Islamic world: partnership for stability", $24^{\text {th }}$ September 2009.

Speech of Yuriy Luzhkov at the Conference "Russia and Islamic world: partnership for stability", $24^{\text {th }}$ September 2009.

Vetchinova, M. Foreign language education is a key to dialogue between cultures. URL: http://www.lihachev.ru/pic/site/files/lihcht/2011_Sbornik/Tom_1/006_Sekcia_6/005_VetchinovaM N.pdf

Yakovets, Yu. \& Farah, S. (2014). Dialogue and partnership of civilizations. The Institute of Economic Strategies. Moscow. 